\title{
Examination and statistical evaluation of physico-chemical parameters of windrow composting
}

\author{
Edit Gorliczay $^{1}$ - János Tamás ${ }^{1}$ - Sándor Kun ${ }^{1}$ - László Huzsvai ${ }^{2}$ - László Bárány ${ }^{3}$ \\ ${ }^{1}$ University of Debrecen, Faculty of Agricultural and Food Sciences and Environmental Management \\ Institute of Water and Environmental Management, Debrecen \\ ${ }^{2}$ University of Debrecen, Faculty of Economics and Business Institute of Statistics and Methodology, Debrecen \\ ${ }^{3}$ Mastergood Ltd., Kisvárda \\ edit.gorliczay@agr.unideb.hu
}

\begin{abstract}
SUMMARY
The treatment and utilization of plant and animal waste and by-products from agriculture is very diverse. Traditional environmental management practices for waste management have been retained through soil conservation and the applied of recycle degradable organic substances in soil. The management of by-products from agriculture (animal husbandry) is important because a closed loop can be created to utilize by-products (manure, feathers) from the production of the main product (eggs, meat, milk) and to form a raw material for a new product. It is important to treat the resulting by-products, especially deep-litter manure, as it has served as a basis for compost-treated manure to develop an organic-based, soil-conditioning product line. Poultry manure by itself is not suitable as a substrate for aerobic decomposition, so it has to be mixed with other substances (zeolite, bentonite, soil), because of its high nutrient capacity, it is an acidifying substance.

The aim of this study was to compost the mixture of poultry manure and hen manure by the addition of zeolite and to monitor the composting process. It was also our aim to statistically determine the effect of the zeolite on parameters describing the composting process.

The windrow composting experiments were set up in the composting area of the University of Debrecen, Institute of Water and Environmental Management. The composting experiment was 62 days long, during which the main parameters describing the composting process were continuously monitored: temperature $\left({ }^{\circ} \mathrm{C}\right)$, moisture content (w/w\%), electrical conductivity (mS/cm), organic matter content (w/w\%), examination of nitrogen forms (w/w\%). In this study, three factors were investigated: temperature, humidity, and pH. For statistical evaluation, $R$ software and RStudio user interface were used. We developed a repeated measurement model, in which the fixed and random effects were determined for our parameters under study, and the resulting relationships were shown on interaction plots.

Based on our results, the temperature of the prisms has become independent of the ambient temperature and the composting stages can be separated in both the control and the zeolite treated prisms. In the repeated measurement model, we proved that treatment, time and treatment: time interaction were significant at both temperature and $\mathrm{pH}$.
\end{abstract}

Keywords: composting, manure, physico-chemical parameters, statistical parameters

\section{INTRODUCTION}

In Hungary, most of the livestock production has been concentrated on large farms in the last twenty years, mainly in the cattle, sheep and poultry farms generating a large amount of manure. However, this manure is considered to be doubly polluting without treatment. Double pollution is due to the fact that nutrients and pathogenic microorganisms in untreated manure can potentially endanger surface and groundwater, and chemical fertilizers used to replace organic fertilizers can also cause environmental problems (Gerber et al., 2007; Kocsis, 2005). Manure need to be treated until application, which means that we have to control the mineralization processes. Composting is a sustainable way of handling manure, as it is a large-scale manure by-product that can be turned into a useful product (Raut et al., 2008).

Poultry manure is contains less water, more nitrogen, phosphorus and potassium than other animal manure, and is also rapidly degradable and compostable (Loch-Nosticzius, 2004). The nitrogen content of laying hen manure is $23.6 \mathrm{~kg} / \mathrm{m}^{3}$ and that of broiler manure is $24.5 \mathrm{~kg} / \mathrm{m}^{3}$ (Gaál, 2011). Composting is a biological oxidative decomposition process that produces a stable material that is similar to natural processes in soil (De Bertoldi et al., 1982). Composting is a directed, aerobic process in which organic matter is decomposed by autothermal and thermophilic biological and chemical oxidation to form large humin molecules (Dunst, 1991). The organic fractions of the materials to be composted are converted into humus and various forms (Kovács, 2019). Poultry manure is unstable, so it is important to add some bulking agents when composting. The additive has several roles in composting, on the one hand, increasing the efficiency of the process and improving the properties of the end product (Hunyadi, 2012).

The end product of composting is compost, which is a complex, stable material, and one of the key tools for keeping organic materials in the cycle (Béres et al., 2016). In addition to examining compost, it is important to understand the processes that occur during composting. Maturity and stability are important, which greatly determines the use of compost. Organic matter is transformed in compost through humification and mineralization, and the monitoring of these processes is essential (Kovács, 2019). Stable compost is considered mature, as unstable compost heats up, produces stinking gases, and can mold (Kovács-Füleky, 2016). The additive is also important because it can adsorb ammonia released during manure treatment (Szöllősi et al., 2018). 


\section{MATERIALS AND METHODS}

Experiments were set up and the laboratory test were carried out at the University of Debrecen, Faculty of Agricultural and Food Sciences and Environmental Management, Institute of Water- and Environmental Management. The broiler and hen manure source was the deep litter husbandry units of the Baromfi-Coop
Ltd. located in Nyírjákó, Hungary. The bulking agent used was zeolite, which was derived from Mád.

The windrow composting experiment was 62 days long. It was composed of broiler manure ( $2 / 3$ volume) and hen manure (1/3 volume) (Table 1). Samples were taken from several points of the compost prisms and taken every three days, and the average sample was used to test them.

Applied settings of windrow composting

\begin{tabular}{cc}
\hline Name of treatments & Mixed raw materials \\
\hline Control & $26.66 \mathrm{~kg}$ broiler manure $+13.33 \mathrm{~kg}$ hen manure $+0 \mathrm{~kg}$ zeolite \\
$1 \mathrm{w} / \mathrm{w} \%$ zeolite & $26.66 \mathrm{~kg}$ broiler manure $+13.33 \mathrm{~kg}$ hen manure $+0.4 \mathrm{~kg}$ zeolite \\
$2 \mathrm{w} / \mathrm{w} \%$ zeolite & $26.66 \mathrm{~kg}$ broiler manure $+13.33 \mathrm{~kg}$ hen manure $+0.8 \mathrm{~kg}$ zeolite \\
$5 \mathrm{w} / \mathrm{w} \%$ zeolite & $26.66 \mathrm{~kg}$ broiler manure $+13.33 \mathrm{~kg}$ hen manure $+2.0 \mathrm{~kg}$ zeolite \\
$7 \mathrm{w} / \mathrm{w} \%$ zeolite & $26.66 \mathrm{~kg}$ broiler manure $+13.33 \mathrm{~kg}$ hen manure $+2.8 \mathrm{~kg}$ zeolite \\
\hline
\end{tabular}

The temperature measurements of compost prisms were done in situ, with PT 100 temperature meter. Temperature measurements were made at $12 \mathrm{~cm}$ depths of the windrow. The "front" point in the windrow longitudinal section corresponds to the $15 \mathrm{~cm}$ section, the "center" point corresponds to the windrow's $35 \mathrm{~cm}$ section, and the "end" point corresponds to the windrow's $55 \mathrm{~cm}$ section. The figures showing the temperature evolution show the average temperature data at the three points.

The moisture content of the fresh samples was determined as weight loss upon drying at $105^{\circ} \mathrm{C}$ in an oven for 24 hours (MSZ-08-0221-1:1979). The $\mathrm{pH}$ of the sample were measured using a 1:10 (w/w, compost/water ratio) sample to deionized water extract. Then, the mixture was stirring 24 hours. After this solution was filtered and the $\mathrm{pH}$ and electrical conductivity was measured using Hanna Instruments 2550 .

Statistical analysis was performed using R software in an R Studio user environment (R Core Team, 2017). We created a repeated measurement (two-factor mixed) model, which is an extension of the paired t-test to more than two times, groups. It is a mixed model because it has both fixed and random effects. In our case, the fix effect is the treatment, and the random effect is time (Huzsvai-Balogh, 2015). The database contained five variables: windrow ID, treatment, weeks, temperature, $\mathrm{pH}$. The treatment has five values: control, one zeolite, two zeolite, five zeolite, seven zeolite. The windrow ID contained the ID's of the prisms, even time were weeks of composting. In the repeated measurement model the significance level was $5 \%$.

\section{RESULTS AND DISCUSSION}

\section{Temperature}

The temperature changes of the control windrow are shown in Figure 1. The lines in the figure separated by a line, represent the stages of composting.
The temperature of the control prism followed the evolution of the outside temperature (Figure 1), but it can also be said that the prism became independent of the ambient temperature. The mixing was followed by a sampling to determine the amount of water needed to moisten to $60 \mathrm{w} / \mathrm{w} \%$, i.e., after heat production started, as can be seen from the temperature of day 1. Based on these values, an initiation phase of composting can be observed on day 1 , which is accompanied by a rapid increase in temperature. By day 12 , there was a very intense heat-producing phase, with the highest temperature measured on day $2\left(64.1^{\circ} \mathrm{C}\right)$. The minimum points on the temperature curve indicate the days when a large amount of water was applied, which resulted in a decrease in temperature. By day 62, the temperature of the prism decreased and raised the ambient temperature. This indicated to us that the material reached the maturation stage. Based on the temperature profile of the prism, the composting were completed within 62 days.

In the control prism, the initiation phase was at the first 24-36 hours. Between 2-15 days was the thermophilic phase, which time the temperature of the prism has exceeded the ambient temperature. The mesophilic phase can be observed for 16-37 days, during which the temperature gradually decreases and the temperature in the windrow was $37.8-25.6^{\circ} \mathrm{C}$. From day 38 , the maturation phase was observed, during which the prism took over the ambient temperature and heat production was gradually stopped.

When the increasing amount of zeolite was mixed, it was found that the length of the thermophilic phase was increased compared to the control. The maximum temperature was measured on day $2\left(62.6-63.6^{\circ} \mathrm{C}\right)$ for each of the three prisms mixed with the zeolite. Based on these results, it can be said that with the addition of a small proportion of zeolite, the thermophilic phase was completed, followed by the mesophilic phase and then maturation on the temperature curve of the prism.

Figure 2 shows the temperature evolution of the windrow mixed with $7 \mathrm{w} / \mathrm{w} \%$ zeolite. 
Figure 1: Temperature evolution in the control windrow

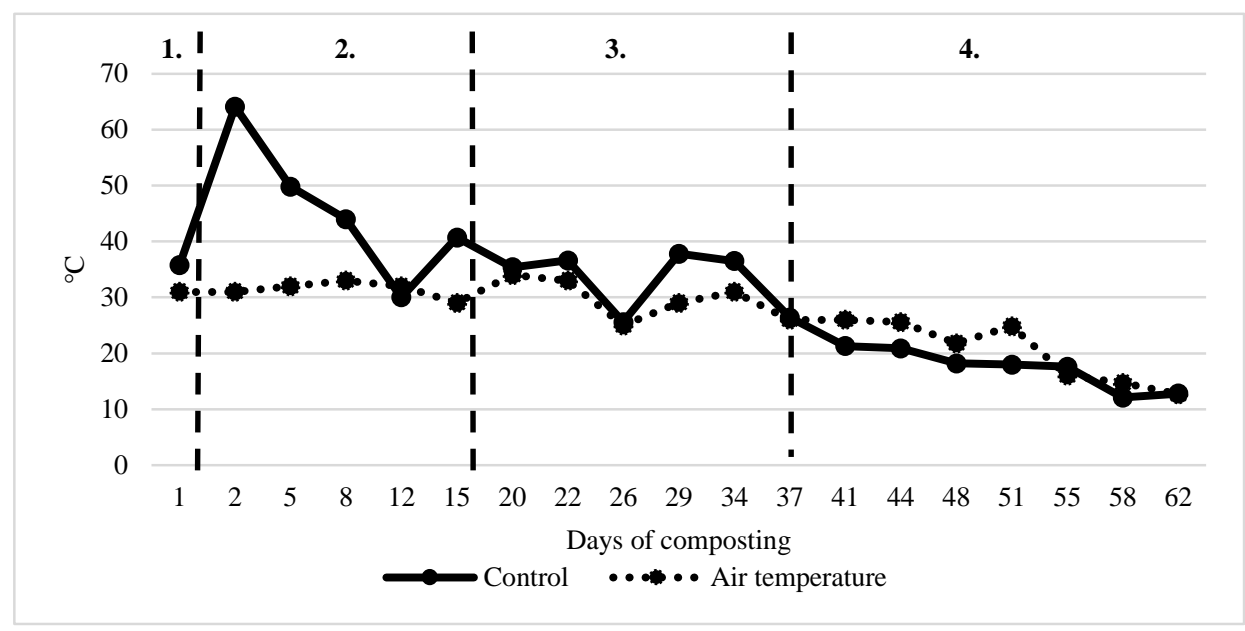

Figure 2: Temperature evaluation of the windrow mixed 7 w/w $\%$ zeolite

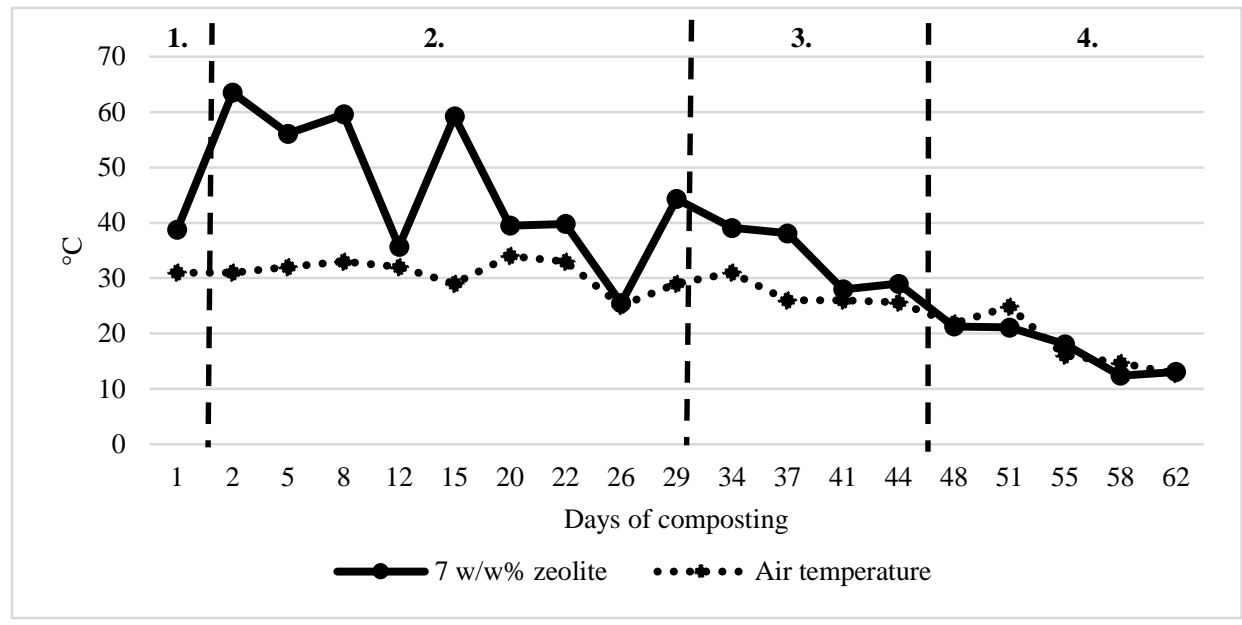

In the $7 \mathrm{w} / \mathrm{w} \%$ zeolite prism, the composting sections have the same temperature profile in the prism as in the control, but the length of each section is different. The initiation phase (Stage 1) lasted 24-36 hours, which is also equivalent to the rapid warm-up phase after wetting. The thermophilic phase (Stage 2) from day 2 to day 29, where the minimum points on the temperature curve indicate the days when a large amount of water was applied, which resulted in a decrease in temperature. The maximum temperature measured in the thermophilic phase was $63.5^{\circ} \mathrm{C}$, while the minimum temperature was $25.5^{\circ} \mathrm{C}$. From day 30, the mesophilic phase (Stage 3 ) is observed, which is also indicated by a gradual decrease in temperature. At day 48 , the maturation phase began (Stage 4), during which the temperature of the windrow was reduced to ambient temperature and no heat was produced.

The increase in the length of the thermophilic phase can be explained by the positive effect of the zeolite on the raw materials: it improved the air supply of the prism and thus had a positive effect on the temperature.
Based on these results, it can be concluded that larger amounts of zeolite can be increased in the thermophilic phase length and higher starting temperatures can be achieved with optimum humidity levels.

We also statistically evaluated the temperature data by constructing a repeated measurement model. The model was constructed so that the fixed effect was treatment, the random effect was time (weeks), and the random variation was the windrow ID/week.

The results of the model are summarized in Table 2 .

Table 2

Result of repeated measurement model at temperature $(\mathbf{p}<0.05)$

\begin{tabular}{cccc}
\hline Factor & $\begin{array}{c}\text { Degree of freedom } \\
(\mathrm{Df})\end{array}$ & F-value & p-value \\
\hline treatment & 4 & 5.762 & $0.116^{*}$ \\
week & 8 & 348.28 & $<2 \mathrm{e}-16^{*}$ \\
treatment:week & 32 & 54.03 & $1.97 \mathrm{e}-06^{*}$ \\
\hline
\end{tabular}


Based on the results of the applied statistical model it can be said that the treatment factor significantly influences the temperature of the prisms. This means that there are differences in the temperature development between the control and the zeolitetreated prisms, which can be confirmed by in situ measurements (Figure 3).
The effect of the time factor also shows a significant difference, as the temperature of prisms changes (increases or decreases depending on the composting stage). The most important aspect of the composting experiment is the significance of the treatment:time (week) interaction. It was shown that the effect of the treatment depends on the composting time.

Figure 3: Interaction plot of temperature

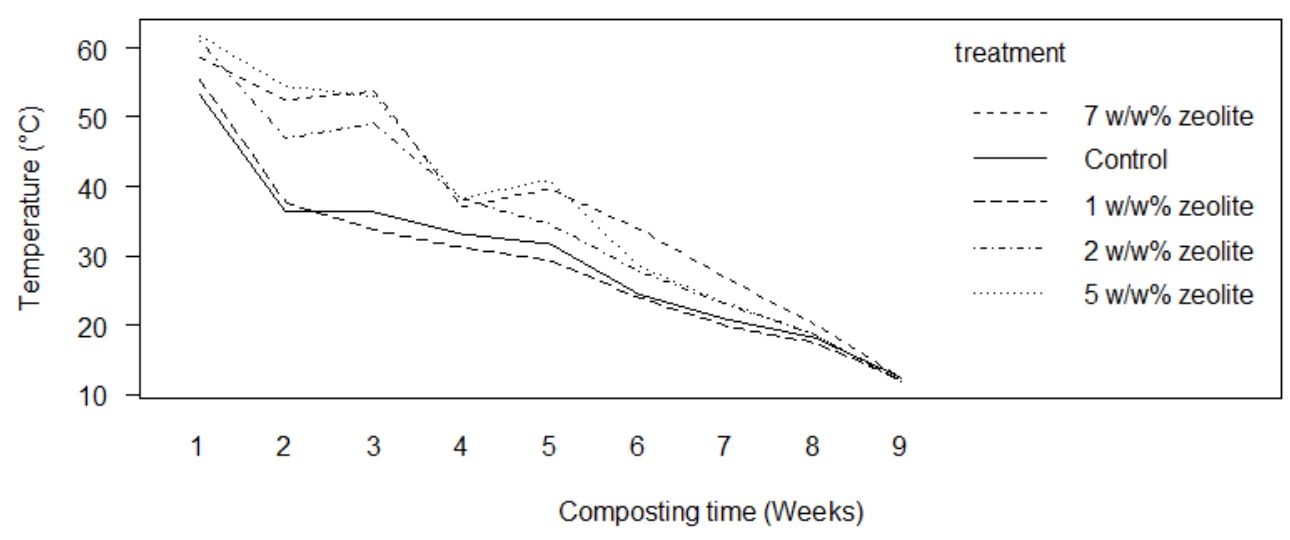

\section{Evaluation of pH}

$\mathrm{pH}$ is also one of the most important factors that play a role in composting. The $\mathrm{pH}$ has a major effect on biodegradation by influencing the activity of microorganisms involved in the composting process, thereby increasing and decreasing biodegradation. The $\mathrm{pH}$ values for the control windrow are shown in Figure 4 , but the $\mathrm{Y}$-axis could start from $\mathrm{pH} 6$ for better representation of the results.

\section{Figure 4: $\mathbf{p H}$ values of the control windrow}

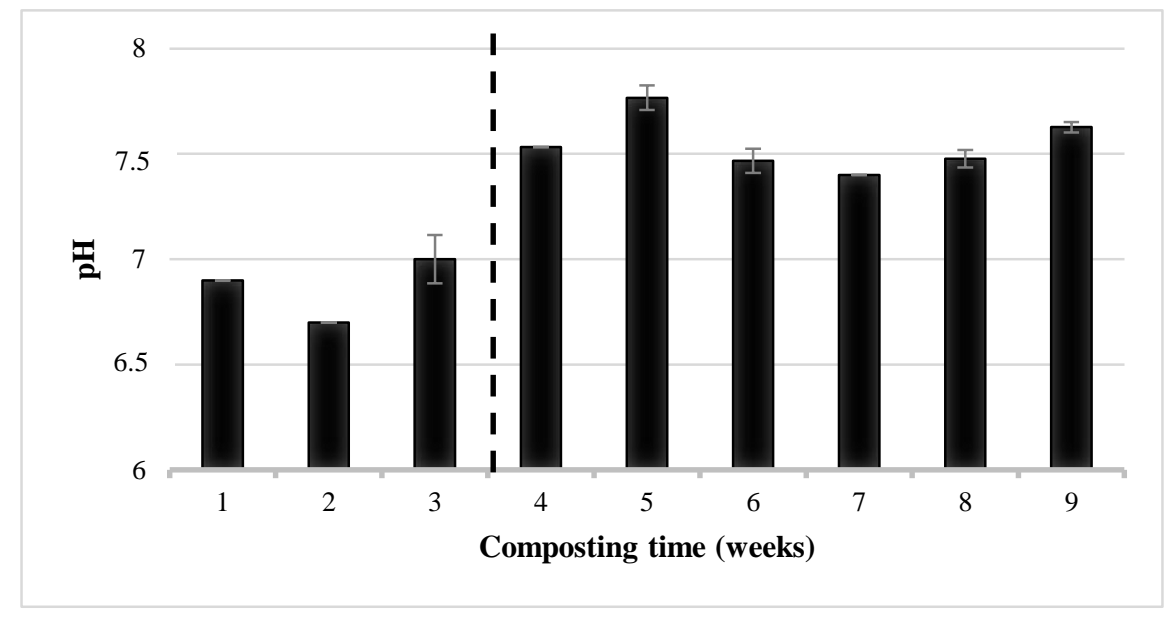

The $\mathrm{pH}$ values in the control prism were consistent throughout the 9 weeks of composting, moving throughout the neutral to slightly alkaline range. Between the first and third weeks, there was a minimal decrease, probably due to the formation of organic acids.

According to the related technical literature, the $\mathrm{pH}$ during composting is such that during the initial stage of composting, the $\mathrm{pH}$ decreases due to the formation of organic acids, but later increases in the composting range and ranges from 7-8 (Turan, 2008; Chan et al., 2015).

The $\mathrm{pH}$ measured in the zeolite mixed prisms is shown in Figure 5. 
Figure 5: $\mathbf{p H}$ values of the zeolite mixed windrows

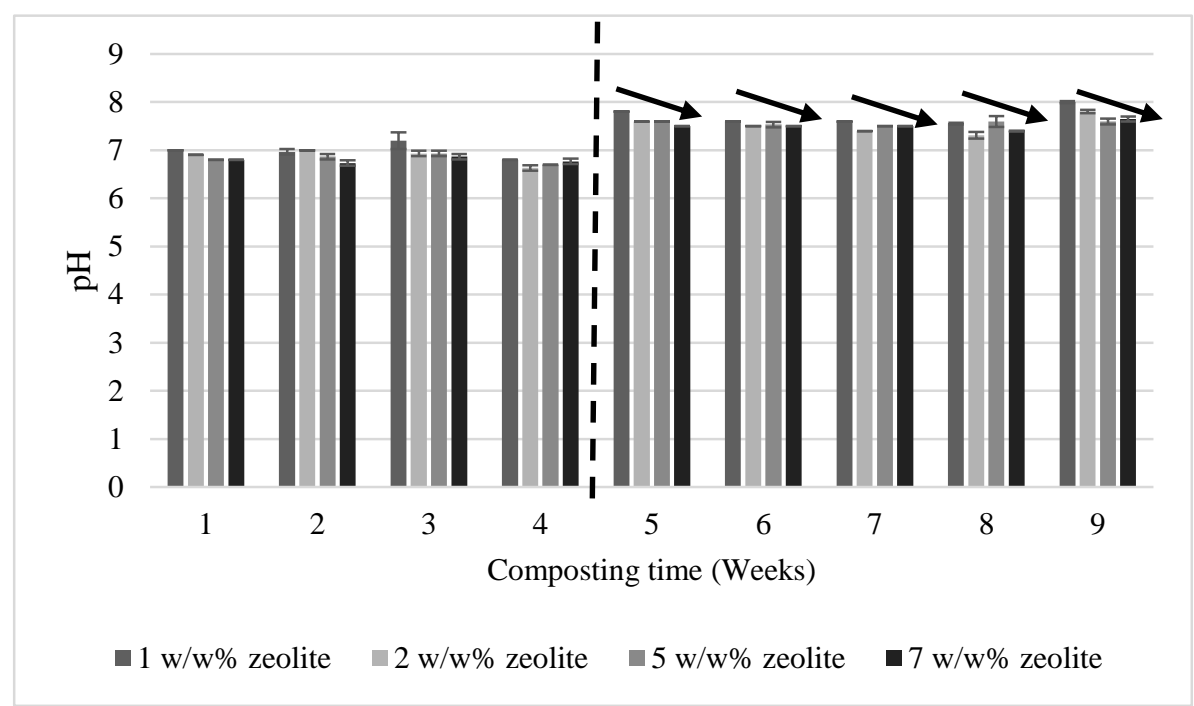

In the prisms mixed with zeolite there is a difference between weeks 1-4 and weeks 5-9. During the first four weeks, due to the increase in organic acids, the $\mathrm{pH}$ was lower than in the following weeks. In addition, the higher the proportion of zeolite mixed in, the greater the reduction in the $\mathrm{pH}$. When the $1 \mathrm{w} / \mathrm{w} \%$ zeolite was mixed, the amount of zeolite in the prism was so small that the $\mathrm{pH}$ of the mixture of broiler and chicken manure could be measured. On the other hand, in the case of prisms mixed with larger amounts of zeolite, the zeolite can adsorb not only ammonia but other exchangeable ions (cation exchange capacity). In the zeolite, the adsorption of the hydrogen ion on the particles is weak, resulting in competition between the individual ions at the binding sites. Due to the binding of other ions in the fertilizer to the zeolite surface, the hydrogen ion is not adsorbed, which causes the compost to acidify. This is the reason why the increasing amount of zeolite reduces the $\mathrm{pH}$.

We also statistically evaluated the $\mathrm{pH}$ data by constructing a repeated measurement model (Table 3)
Table 3

Result of repeated measurement model at $\mathrm{pH}$ values $(\mathrm{p}<0.05)$

\begin{tabular}{cccc}
\hline Factor & $\begin{array}{c}\text { Degree of } \\
\text { freedom (Df) }\end{array}$ & F-value & p-value \\
\hline treatment & 4 & 86.64 & $1.02 \mathrm{e}-0.7^{*}$ \\
week & 8 & 856.75 & $<2 \mathrm{e}-16^{*}$ \\
treatment:week & 32 & 16.76 & $<2 \mathrm{e}-16^{*}$ \\
\hline
\end{tabular}

There were statistically and analytically different differences between the control and zeolite treated prisms (Figure 6). The effect of the time factor also shows a significant difference, as the $\mathrm{pH}$ of the prisms changes (increases or decreases depending on the composting stage).

The most important aspect of the composting experiment is the significance of the treatment:week interaction. This proved statistically that the effect of the treatment depends on the composting time.

Figure 6: Interaction plot of pH

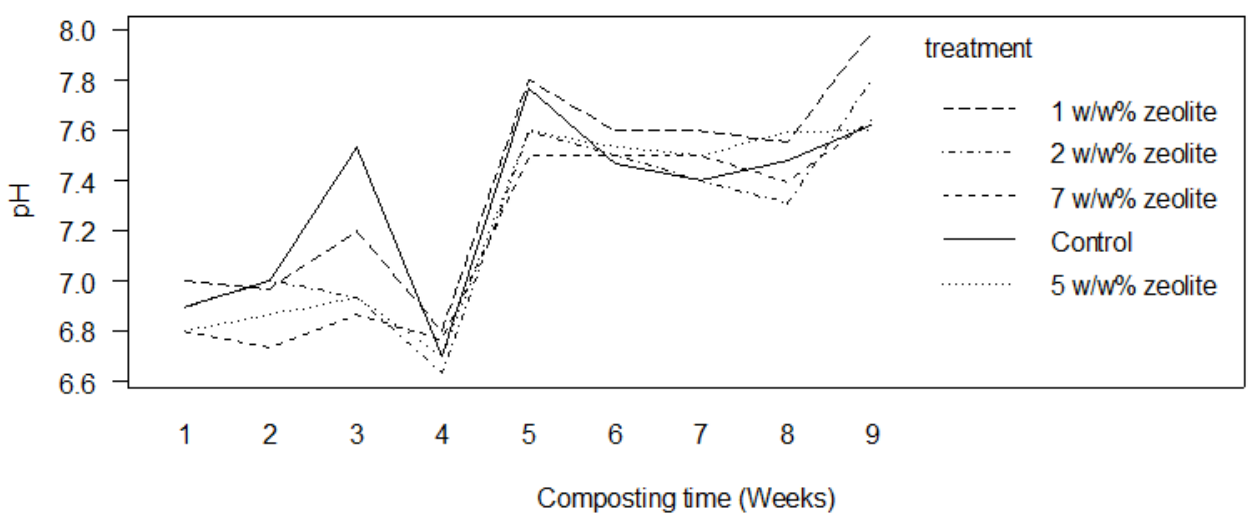




\section{CONCLUSIONS}

Based on the examination of the physico-chemical properties of windrow composting, it can be said that the temperature developed during composting as described in the literature (De Bertoldi et al., 1982; Dunst, 1991), the four stages of composting was separated. By increasing the proportion of additive, the length of the thermophilic phase can be increased. In the control and treated prisms, the prisms (based on temperature) became independent of the ambient temperature. From the statistical evaluation of temperature, the interaction between treatment, week, and treatment:week interaction was significant. The most important is the significance of treatment:week interaction. This proved statistically that the effect of the treatment depends on the composting time.

In the control prism, the $\mathrm{pH}$ was within the neutral to slightly alkaline range during the 9 weeks of composting. As the mixing ratio of the zeolite increased, the $\mathrm{pH}$ decreased and the compost was acidified.

From the statistical evaluation of the $\mathrm{pH}$, there are statistically and analytically differences in the $\mathrm{pH}$ values between the control and the zeolite treated prisms. For $\mathrm{pH}$ the treatment, week, and treatment:week interaction were significant.

Further studies are underway on the physical, chemical and biological factors of composting and the results are being statistically evaluated.

\section{ACKNOWLEDGEMENTS}

I would like to thank the Baromfi-Coop Ltd.for providing the base material for our experiments.

This research was supported by EU grant to Hungary; GINOP 2.2.1.-15-2017-00043.

The publication is supported by the EFOP-3.6.3VEKOP-16-2017-00008 project. The project is cofinanced by the European Union and the European Social Fund.

\section{REFERENCES}

Béres, A.-Csiffáry, N.-Gadácsi, R.-Laczkó, B.-Márton, Zs. (2016) A komposzt is érték! A helyben végzett komposztálás elmétele és gyakorlata. Herman Ottó Intézet, Budapest.

Chan, M. T.-Selvam, A.-Wong, J. W. C. (2015): Reducing nitrogen loss and salinity during struvite food waste composting by zeolite amendment. Bioresource Technology 200 (9), 838-844.

De Bertoldi, M. D.-Vallini, G.-Pera, A. (1983): The biology of composting. Waste Management and Research. 1.

Dunst, G. (1991): Kompostierung. Leopold Stocker Verlag. Graz Stuttgart.

Gaál, K. (2011): Trágyakezelés- és hasznosítás baromfitelepeken. In Bogenfürst, F.: Baromfitenyésztés. Kaposvári Egyetem; Pannon Egyetem; Nyugat-magyarországi Egyetem. 383.

Gerber, P.-Opio, C.-Steinfeld, H. (2007): Animal Production and Health Division, Food and Agriculture Organization of the United Nations, Viale delle Terme di Caracalla, 00153 Rome, Italy.

Hunyadi, G. (2012): Hulladékból előállított komposztok degradációs folyamatainak nyomon követése. Doktori értekezés. Debrecen Egyetem, Kerpely Kálmán Növénytermesztési, Kertészeti és Regionális Tudományok Doktori Iskola.

Huzsvai, L.-Balogh, P. (2015): Lineáris modellek az R-ben. Seneca Books. Debrecen. 150.

Kocsis, I. (2005): Komposztálás, Szaktudás Kiadó Ház Rt., Budapest, 209.
Kovács, D.-Füleky, Gy. (2016): Methods for determining compost maturity - Review (in Hungarian: A komposztérettség meghatározásának módszerei - Szemle). Agrokémia és talajtan, 65:135-160.

Kovács, D. (2019): A komposztálás folyamatának nyomonkövetése új vizsgálati módszer alkalmazásával. Doktori értekezés. Szent István Egyetem, Gödöllő. p.154.

Loch, J.-Nosticzius, Á. (2004): Agrokémia és növényvédelmi kémia. Mezőgazda Kiadó. Budapest. p. 360.

R Core Team (2017): R: A language and environment for statistical computing. R Foundation for Statistical Computing, Vienna, Austria. URL https://www.Rproject.org/.

Raut, M. P.-William, S. M. P. P.-Bhattacharyya, J. K.-Chakrabarti, T.-Devotta, S. (2008): Microbial dynamics and enzymeactivities during rapid composting of municipal solid waste - a compost maturity analysis perspective. Bioresource Technology 99, $6512-6519$

Szöllősi, N.-Blaskó, L.-Bozsik, É.-Gálya, B.-Mézes, L.-Petis, M.Tamás, J.-Borbély, J. (2018): Immobilization of ammonia generated in poultry manure; reduction of environment impact. Natural Resources and Sustainable Development. Vol. 8. Issue 1. 41-48.

Turan, N. G. (2008): The effects of natural zeolite on salinity level of poultry litter compost. Bioresource Technology. 99, 2097-2101. 